\section{Case Report}

\author{
Correspondence \\ J. R. Iredell \\ jiredell@sydney.edu.au
}

Received 29 December 2010

Accepted 4 July 2011

\title{
Bacteriophage therapy for refractory Pseudomonas aeruginosa urinary tract infection
}

\author{
A. Khawaldeh, ${ }^{1}+$ S. Morales, ${ }^{2}$ B. Dillon, ${ }^{1}$ Z. Alavidze, ${ }^{3}$ A. N. Ginn, ${ }^{1}$ \\ L. Thomas, ${ }^{1}$ S. J. Chapman, ${ }^{1}$ A. Dublanchet, ${ }^{4}$ A. Smithyman ${ }^{2}$ \\ and J. R. Iredell ${ }^{1,5}$ \\ ${ }^{1}$ Centre for Infectious Diseases and Microbiology, Sydney West Area Health Service, NSW 2145, \\ Australia \\ ${ }^{2}$ Special Phage Services Pty, Brookvale, Sydney, NSW, Australia \\ ${ }^{3}$ Eliava Institute of Bacteriophage, Microbiology and Virology, Georgian Academy of Sciences, \\ Tbilisi, Democratic Republic of Georgia \\ ${ }^{4}$ GEEPhage, CHI Villeneuve St Georges, Villeneuve St Georges, France \\ ${ }^{5}$ Sydney Institute for Emerging Infection and Biotechnology, University of Sydney at Westmead \\ Hospital, NSW 2145, Australia
}

We describe the success of adjunctive bacteriophage therapy for refractory Pseudomonas aeruginosa urinary tract infection in the context of bilateral ureteric stents and bladder ulceration, after repeated failure of antibiotics alone. No bacteriophage-resistant bacteria arose, and the kinetics of bacteriophage and bacteria in urine suggest self-sustaining and self-limiting infection.

\section{Introduction}

Pseudomonas aeruginosa is an opportunistic human pathogen associated with biofilm infections refractory to antibiotic therapy, particularly in cystic fibrosis and burn wounds and in other immunocompromised hosts (Azeredo \& Sutherland, 2008; Fothergill et al., 2010). Lytic bacteriophage has long been known to have the potential to deliver effective targeted therapy (Himmelweit, 1945), including for $P$. aeruginosa, and increasing antibiotic resistance has sparked renewed interest in this approach (Azeredo \& Sutherland, 2008; Kutter et al., 2010; Harper \& Enright, 2011).

\section{Case report}

A 67-year-old woman underwent extensive intra-abdominal resections and pelvic irradiation for adenocarcinoma followed by bilateral ureteric stent placement to relieve obstruction. This was complicated by symptomatic $P$. aeruginosa infection, for which she received multiple courses of gentamicin, ceftazidime, ciprofloxacin and meropenem over a 2 year period, and two stent replacements. Symptomatic relapse with $P$. aeruginosa susceptible to ciprofloxacin (MIC $\left.0.25 \mu \mathrm{g} \mathrm{ml})^{-1}\right)$, gentamicin $(2 \mu \mathrm{g}$ $\mathrm{ml}^{-1}$ ), ceftazidime $\left(4 \mu \mathrm{g} \mathrm{ml}{ }^{-1}\right.$ ) and meropenem (MIC $2 \mu \mathrm{g} \mathrm{ml}^{-1}$; determined by Etest performed according to

†Present address: Department of Medicine, King Hussein Medical Centre, Amman, Jordan.

Abbreviation: MT-PCR, multiplexed tandem PCR. manufacturer's instructions; Etest, $\mathrm{AB}$ bioMérieux) occurred usually within a week after ceasing antibiotics, always at $>10^{5}$ c.f.u. $\mathrm{ml}^{-1}$ and in association with pyuria $(>100$ white blood cells $\mathrm{ml}^{-1}$ ) and haematuria.

Several isolates of the infecting $P$. aeruginosa strain were screened against existing bacteriophage libraries at the Eliava Institute in Tbilisi (Democratic Republic of Georgia, DPR) which have been used extensively to treat patients (Kutter et al., 2010; Stone, 2002). Six lytic bacteriophages, each at a titre of $10^{6}$ p.f.u. $\mathrm{ml}^{-1}$ against the target $P$. aeruginosa, were combined into a filter-sterilized bacteriophage product (Pyophage \#051007) licensed under DPR Ministry of Health guidelines (Stone, 2002; Sulakvelidze et al., 2001). Routine bacterial culture on chocolate agar (Difco) at $37^{\circ} \mathrm{C}$ of a sample vial was again negative in the Centre for Infectious Diseases and Microbiology Laboratory Services laboratory.

Ethical approval was obtained from the Western Sydney Human Research Ethics Committee on a compassionate use basis, and informed consent was obtained from the patient. The patient was hospitalized and $20 \mathrm{ml}\left(\sim 2 \times 10^{7}\right.$ p.f.u.) Pyophage \#051007 was instilled directly into the bladder every $12 \mathrm{~h}$ for 10 days, with the catheter clamped for $30 \mathrm{~min}$ after each instillation. Urine was collected before treatment and at $4 \mathrm{~h}$ intervals after the morning dose for the first 2 days, and then each morning prior to bacteriophage and antibiotic treatment. The catheter was changed on days 3 and 10. Meropenem ( $1 \mathrm{~g}$ twice daily) and colistin (polymixin E, $100 \mathrm{mg}$ twice daily) commenced 
on day six. Colistin was used for a total of 5 days (days 610) and the patient was discharged home on intravenous meropenem alone after day 10 , to complete a total meropenem course of 30 days.

Both stents were removed for a third time and the right ureteric stent was reinserted while still on meropenem (day 20). Cystoscopy at that time revealed an inflamed bladder with bilateral lower ureteric strictures and an ulcerated bladder base. Midstream urine sampled every 8 weeks remained sterile for 6 months after completion of antibacterial treatment, during which time the patient remained asymptomatic. Intermittent haematuria continued but no further antibiotic therapy was used. Urine cultures were negative when the patient was admitted with recurrent intra-abdominal malignancy a year later.

\section{Microbiological studies}

For quantifying bacteriophage in urine, samples were diluted $1: 1$ in $0.9 \%(\mathrm{w} / \mathrm{v})$ PBS, filtered through a $0.2 \mu \mathrm{m}$ filter and evaluated in an overlay assay with the relevant $P$. aeruginosa strain. All assays were performed in triplicate. Serial dilutions of urine were also incubated aerobically on blood agar (Oxoid) at $37{ }^{\circ} \mathrm{C}$ for bacterial colony counts. All P. aeruginosa and Enterococcus faecalis isolates were tested against the bacteriophage cocktail: $100 \mu \mathrm{l} \sim 10^{6}$ c.f.u. exponential phase organisms $\mathrm{ml}^{-1}$ in $3 \mathrm{ml} 0.4 \%$ nutrient agar (NA; Difco) at
$50{ }^{\circ} \mathrm{C}$ was overlaid onto $0.8 \%$ NA and allowed to solidify at $25^{\circ} \mathrm{C}$ for $20 \mathrm{~min} ; 5 \mu \mathrm{l}$ bacteriophage serially diluted in modified Tris buffer $[5 \mathrm{ml} 2 \%(\mathrm{w} / \mathrm{v})$ gelatin in $50 \mathrm{ml} 1.0 \mathrm{M}$ Tris/HCl (pH 7.0) with $5.8 \mathrm{~g} \mathrm{NaCl} \mathrm{l}^{-1}, 2.0 \mathrm{~g} \mathrm{MgSO}_{4} .7 \mathrm{H}_{2} \mathrm{O}$ $\mathrm{I}^{-1}$ ] was adsorbed into the overlay. Plaques were counted after $18 \mathrm{~h}$ aerobic incubation at $37^{\circ} \mathrm{C}$. To establish the frequency of resistance to bacteriophages after the therapeutic intervention, the bacteriophage preparation was applied as above in 10 -fold dilutions (neat to $1: 10^{4}$ ) onto bacterial lawns prepared from phage-treated samples days 1, 3 and 7. Bacteriophage was enumerated in urine by dilution as above. All assays were performed in triplicate.

Two hundred microlitre aliquots of urine were also extracted (GenElute Mammalian DNA Extraction kit; Sigma-Aldrich) for bacterial DNA load estimation, as were control strains (suspended at $\sim 10^{3}$ c.f.u. $\mathrm{ml}^{-1}$ in sterile $0.9 \%$, w/v, $\mathrm{NaCl}$ ). The 16S rDNA of Enterobacteriaceae, Pseudomonas species, Enterococcus species, Streptococcus species and Staphylococcus species was quantified by multiplexed tandem PCR (MTPCR) (Bacterial Count; AusDiagnostics), essentially as previously described (Szewczuk et al., 2010), in a RotorGene RG6000 cycler (Corbett Research). Limits of detection were determined as the means of three different experiments using sterile urine spiked with $P$. aeruginosa ATCC 27853 (183 c.f.u. $\mathrm{ml}^{-1}$; 1.5 c.f.u. per reaction), Escherichia coli ATCC 25922 (3733 c.f.u. $\mathrm{ml}^{-1}$; 30 c.f.u. per reaction), E. faecalis ATCC 29212 (1719 c.f.u. $\mathrm{ml}^{-1}$; 14 c.f.u. per reaction),

Table 1. $P$. aeruginosa viable count (c.f.u. $\mathrm{ml}^{-1}$, by serial dilution and culture), DNA load of Enterococcus and $P$ seudomonas species [by MT-PCR, both expressed in c.f.u. $(\mathrm{ml} \text { urine })^{-1}$ ] and bacteriophage titre against original $P$. aeruginosa isolate [approx. p.f.u. (ml urine $)^{-1}$

Antibiotics were present from day 6 after pre-dose sampling (bold).

\begin{tabular}{|c|c|c|c|c|}
\hline & \multirow{2}{*}{$\begin{array}{l}\text { Bacterial viable count } \\
\quad\left(\text { c.f.u. } \mathrm{ml}^{-1}\right)^{\star}\end{array}$} & \multicolumn{2}{|c|}{ Bacterial DNA load (c.f.u. $\mathrm{ml}^{-1}$ ) } & \multirow{2}{*}{$\begin{array}{l}\text { Phage titre } \\
\text { (p.f.u. } \mathbf{~ m l}^{-1} \text { ) }\end{array}$} \\
\hline & & Enterococcus c.f.u. (mean $\pm \mathrm{SD}$ ) & Pseudomonas c.f.u. $($ mean \pm SD) & \\
\hline Day 1 (start) & $3.00 \times 10^{6}$ & $3.10 \times 10^{7} \pm 1.45 \times 10^{7}$ & $4.27 \times 10^{5} \pm 1.42 \times 10^{5}$ & 0 \\
\hline Day $1(+4 \mathrm{~h})$ & $1.60 \times 10^{5}$ & $5.41 \times 10^{6} \pm 9.18 \times 10^{5}$ & $4.92 \times 10^{4} \pm 1.78 \times 10^{4}$ & $3.09 \times 10^{3}$ \\
\hline Day $1(+8 \mathrm{~h})$ & $2.40 \times 10^{5}$ & $8.59 \times 10^{6} \pm 7.87 \times 10^{5}$ & $5.70 \times 10^{4} \pm 1.03 \times 10^{4}$ & $4.30 \times 10^{3}$ \\
\hline Day $1(+12 \mathrm{~h})$ & $(-)$ & $8.59 \times 10^{5} \pm 1.07 \times 10^{5}$ & $1.53 \times 10^{4} \pm 2.27 \times 10^{3}$ & $5.30 \times 10^{4}$ \\
\hline Day 2 (pre-) & $3.00 \times 10^{5}$ & $3.85 \times 10^{6} \pm 4.44 \times 10^{4}$ & $8.37 \times 10^{4} \pm 2.20 \times 10^{4}$ & $1.60 \times 10^{6}$ \\
\hline Day $2(+4 \mathrm{~h})$ & $1.12 \times 10^{5}$ & $9.43 \times 10^{6} \pm 9.54 \times 10^{6}$ & $3.58 \times 10^{5} \pm 1.68 \times 10^{5}$ & $1.40 \times 10^{6}$ \\
\hline Day $2(+8 \mathrm{~h})$ & $3.00 \times 10^{5}$ & $2.91 \times 10^{6} \pm 1.61 \times 10^{3}$ & $3.03 \times 10^{4} \pm 4.43 \times 10^{4}$ & $9.30 \times 10^{5}$ \\
\hline Day $2(+12 \mathrm{~h})$ & $3.00 \times 10^{5}$ & $1.31 \times 10^{6} \pm 3.99 \times 10^{5}$ & $7.55 \times 10^{4} \pm 5.81 \times 10^{3}$ & $9.30 \times 10^{5}$ \\
\hline Day 3 (pre-) & $3.00 \times 10^{5}$ & $3.77 \times 10^{6} \pm 1.57 \times 10^{6}$ & $3.87 \times 10^{4} \pm 6.17 \times 10^{4}$ & $2.30 \times 10^{4}$ \\
\hline Day 4 (pre-) & $(-)$ & $2.82 \times 10^{6} \pm 7.55 \times 10^{5}$ & $2.66 \times 10^{4} \pm 8.14 \times 10^{2}$ & $3.70 \times 10^{5}$ \\
\hline Day 5 (pre-) & $3.00 \times 10^{5}$ & $1.38 \times 10^{7} \pm 3.12 \times 10^{5}$ & $2.25 \times 10^{5} \pm 3.02 \times 10^{4}$ & $9.30 \times 10^{5}$ \\
\hline Day 6 (pre-) & $6.40 \times 10^{4}$ & $2.69 \times 10^{6} \pm 2.85 \times 10^{5}$ & $1.94 \times 10^{5} \pm 1.48 \times 10^{5}$ & $3.70 \times 10^{5}$ \\
\hline Day 7 (pre-) & $6.30 \times 10^{3}$ & $1.70 \times 10^{7} \pm 1.48 \times 10^{6}$ & $6.75 \times 10^{4} \pm 3.35 \times 10^{4}$ & $4.00 \times 10^{5}$ \\
\hline Day 8 (pre-) & 0 & $1.93 \times 10^{7} \pm 3.12 \times 10^{6}$ & $8.39 \times 10^{4} \pm 4.29 \times 10^{4}$ & $2.60 \times 10^{4}$ \\
\hline Day 9 (pre-) & 0 & $1.58 \times 10^{7} \pm 1.08 \times 10^{6}$ & $2.57 \times 10^{3} \pm 6.73 \times 10^{2}$ & $1.00 \times 10^{3}$ \\
\hline Day 10 (pre-) & 0 & $9.81 \times 10^{6} \pm 8.57 \times 10^{5}$ & $1.43 \times 10^{3} \pm 5.64 \times 10^{2}$ & 3 \\
\hline Day 21 (pre-) & 0 & $6.66 \times 10^{3} \pm 1.74 \times 10^{3}$ & $\leqslant 10$ & 0 \\
\hline
\end{tabular}

${ }^{*}(-)$, Not tested. 
Streptococcus pneumoniae ATCC 49615 (2022 c.f.u. $\mathrm{ml}^{-1}$; 16 c.f.u. per reaction) and Staphylococcus aureus ATCC 25923 (2718 c.f.u. $\mathrm{ml}^{-1} ; 22$ c.f.u. per reaction). Melt temperatures were consistent in triplicate runs and reproducibility was high (standard curves for all targets $r^{2}$ 0.9922-0.9997; not shown).

Bacteriophage counts remained high until after disappearance of the target organism and then diminished sharply (Table 1). Quantitative PCR data indicated that bacterial DNA persisted beyond the point of culture-positivity, perhaps reflecting the release of dead organisms from biofilms, although experiments were not done to formally evaluate this. Initial viable $P$. aeruginosa counts were $>3 \times 10^{6}$ c.f.u. $\mathrm{ml}^{-1}$ (Table 1). Viable bacterial counts declined before antibiotics commenced on day 6 (logarithmic graph, Fig. 1). DNA fingerprinting by enterobacterial repetitive intergenic consensus-PCR (Versalovic et al., 1991) showed that all $P$. aeruginosa isolates were identical, and all were susceptible to colistin and meropenem and to the bacteriophage cocktail in the same titre. Bacteriophage counts in urine rose from $3 \times 10^{3}$ p.f.u. $\mathrm{ml}^{-1}, 4 \mathrm{~h}$ after the initial dose, to $\sim 5 \times 10^{4}$ p.f.u. $\mathrm{ml}^{-1}$ after $12 \mathrm{~h}$ and to $>10^{6}$ p.f.u. $\mathrm{ml}^{-1} 20 \mathrm{~h}$ later before the first dose on day 2 . Bacteriophage levels remained at at least $\sim 10^{5}$ p.f.u. $\mathrm{ml}^{-1}$ for a week but then fell sharply. Small amounts of bacteriophage were still detectable $\left(\sim 10^{3}\right.$ p.f.u. $\left.\mathrm{ml}^{-1}\right)$ immediately prior to bacteriophage administration on day 9, and none thereafter (Table 1). Cultures and MTPCR detected both Pseudomonas and Enterococcus species in urine. E. faecalis, susceptible to ampicillin but not to bacteriophage, was cultured and Enterococcus species were enumerated by MT-PCR at $\sim 10^{6-7}$ from admission until day 9 , and then fell to $\sim 10^{3}$ c.f.u. $\mathrm{ml}^{-1}$ on discharge from hospital. P. aeruginosa was culturable at $>10^{5}$ c.f.u. $\mathrm{ml}^{-1}$ to day 6 and was quantified by MT-PCR at $1.9 \times 10^{5}$ c.f.u. $\mathrm{ml}^{-1}$ (Table 1), and then in reduced numbers up to day 7 $\left(6.75 \times 10^{4}\right.$ viable c.f.u. $\mathrm{ml}^{-1}$; 10 -fold higher DNA load equivalent), but no antibiotic- or bacteriophage-resistant $P$. aeruginosa was recovered at any stage. $P$. aeruginosa DNA could still be detected by MT-PCR up to day 10 (DNA equivalent to $\sim 10^{3}$ c.f.u. $\mathrm{ml}^{-1}$ ), but not thereafter (Table 1).

\section{Discussion}

Combined therapy was well-tolerated, apparently resulting in symptomatic relief and microbiological cure where repeated courses of antibiotics combined with stent removal had failed. Previous reports indicate that bacteriophage therapy is a safe and potentially effective antipseudomonal treatment (Marza et al., 2006; Rhoads et al., 2009; Wright et al., 2009), although data about the kinetics of bacteriophage infection are scant. Bacteriophage did not persist nor was any antibiotic- or bacteriophageresistant $P$. aeruginosa identified. The additive effort of combined phage-antibiotic treatment has been known since the beginning of the antibiotic era (Himmelweit,

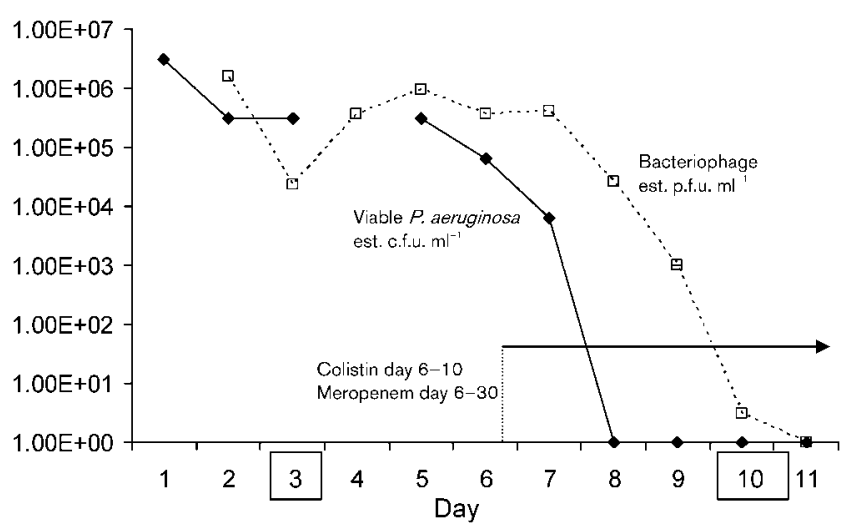

Fig. 1. Logarithmic plot of early morning urine viable $P$. aeruginosa (c.f.u. $\mathrm{ml}^{-1}$ ) and bacteriophage (p.f.u. $\mathrm{ml}^{-1}$ ) counts. Antibiotic administration and catheter change and removal (days 3 and 10, respectively; boxed) are indicated.

1945), but optimal dosing and duration of therapy remain unknowns. The nearly $2 \log$ fall in $P$. aeruginosa concentration in the urine which appeared to precede the administration of antibiotics strongly suggests an action in vivo that mimics that observed in vitro. The data indicate that bacteriophage infection was self-sustaining and selflimiting, with the phage decreasing in number along with the viable target organisms in which they replicated.

\section{Acknowledgements}

A. K. was supported by a Fellowship in Infectious Diseases from the Royal Jordanian Armed Forces, Hashamite Kingdom of Jordan.

\section{References}

Azeredo, J. \& Sutherland, I. W. (2008). The use of phages for the removal of infectious biofilms. Curr Pharm Biotechnol 9, 261-266.

Fothergill, J. L., Mowat, E., Ledson, M. J., Walshaw, M. J. \& Winstanley, C. (2010). Fluctuations in phenotypes and genotypes within populations of Pseudomonas aeruginosa in the cystic fibrosis lung during pulmonary exacerbations. J Med Microbiol 59, 472-481.

Harper, D. R. \& Enright, M. C. (2011). Bacteriophages for the treatment of Pseudomonas aeruginosa infections. J Appl Microbiol 111, 1-7.

Himmelweit, F. (1945). Combined action of penicillin and bacteriophage on Staphylococci. Lancet 246, 104-105.

Kutter, E., De Vos, D., Gvasalia, G., Alavidze, Z., Gogokhia, L., Kuhl, S. \& Abedon, S. T. (2010). Phage therapy in clinical practice: treatment of human infections. Curr Pharm Biotechnol 11, 69-86.

Marza, J. A., Soothill, J. S., Boydell, P. \& Collyns, T. A. (2006). Multiplication of therapeutically administered bacteriophages in Pseudomonas aeruginosa infected patients. Burns 32, 644-646.

Rhoads, D. D., Wolcott, R. D., Kuskowski, M. A., Wolcott, B. M., Ward, L. S. \& Sulakvelidze, A. (2009). Bacteriophage therapy of venous leg ulcers in humans: results of a phase I safety trial. $J$ Wound Care 18, 237-238, 240-243.

Stone, R. (2002). Bacteriophage therapy. Stalin's forgotten cure. Science 298, 728-731. 
Sulakvelidze, A., Alavidze, Z. \& Morris, J. G., Jr (2001). Bacteriophage therapy. Antimicrob Agents Chemother 45, 649-659.

Szewczuk, E., Thapa, K., Anninos, T., McPhie, K., Higgins, G., Dwyer, D. E., Stanley, K. K. \& Iredell, J. R. (2010). Rapid semi-automated quantitative multiplex tandem PCR (MT-PCR) assays for the differential diagnosis of influenza-like illness. BMC Infect Dis 10, 113.
Versalovic, J., Koeuth, T. \& Lupski, J. R. (1991). Distribution of repetitive DNA sequences in eubacteria and application to fingerprinting of bacterial genomes. Nucleic Acids Res 19, 6823-6831.

Wright, A., Hawkins, C. H., Anggård, E. E. \& Harper, D. R. (2009). A controlled clinical trial of a therapeutic bacteriophage preparation in chronic otitis due to antibiotic-resistant Pseudomonas aeruginosa; a preliminary report of efficacy. Clin Otolaryngol 34, 349-357. 